$10-2017$

\title{
Film Review: Stealing a Nation
}

Rahat Imran

University of the Punjab, Lahore, Pakistan

Follow this and additional works at: https://digitalcommons.usf.edu/gsp

\section{Recommended Citation}

Imran, Rahat (2017) "Film Review: Stealing a Nation," Genocide Studies and Prevention: An International Journal: Vol. 11: Iss. 2: 125-128.

DOI:

http://doi.org/10.5038/1911-9933.11.2.1490

Available at: https://digitalcommons.usf.edu/gsp/vol11/iss2/17

This Film Review is brought to you for free and open access by the Open Access Journals at Digital Commons @ University of South Florida. It has been accepted for inclusion in Genocide Studies and Prevention: An International Journal by an authorized editor of Digital Commons @ University of South Florida. For more information, please contact digitalcommons@usf.edu. 
Film Review: Stealing a Nation

\author{
Rahat Imran \\ University of the Punjab \\ Lahore, Pakistan
}

Stealing a Nation

Director: John Pilger

UK, 2004

Reviewed by Rahat Imran

University of the Punjab

Multiple award-winning journalist and documentarist John Pilger's award winning participatory documentary film, Stealing a Nation, takes as its subject the small island of Diego Garcia, one of the Chagos Islands in the Indian Ocean, and the forcible expulsion and displacement of its 2,000 strong indigenous Creole population. ${ }^{1}$ This expulsion was a result of a secret deal struck between the US and Britain under British Prime Minister Harold Wilson's tenure. Stealing a Nation, as the title suggests, traces the systematic cleansing of the Diego Garcia Island, which remains a British crown colony, "swept" and "sanitized", to make way for what became America's largest military base outside of the US, and from where both Iraq and Afghanistan have been attacked in US-led wars and invasions of the respective countries.

Pilger explains the changed human landscape of the Island as one that has transformed the once peaceful and quiet island, referred to by its indigenous population as a "paradise", into one that is now a thriving US military base, inhabited exclusively by American military personnel and their families. Through off-screen narration, detailed archival research and footage, interviews with the indigenous islanders, investigating and referencing British government documents and memos, Pilger's three-part documentary pieces together a neglected and politically manipulated conspiracy and history, exposing the forced expulsion of the islanders through a closely guarded and brutal plot hatched at the highest political levels between the US and British governments for political and strategic gains.

As an expose, Stealing a Nation works on several levels: it provides a space and platform to the otherwise forgotten and silenced indigenous community of Diego Garcia to air and record their individual and collective traumatic memories of violence and injustice; it captures a visual memorializing of Diego Garcia as a political and historical site of violation of human rights and injustice; the film focuses attention on the island as a US military base and site of political connivance that has global importance and implications, as was the case during the US attacks on Iraq (2003), and Afghanistan (2001).

In Part One of the film, archival footage juxtaposes images of Diego Garcia before and after the US troops arrived on the island-turned-military-base in 1961 -a military base, we are told in voiceover, that was so advanced that it cost \$ 1 billion at the time, and was governed from Mauritius, a thousand miles away.

Pilger shows us images of slums, with derelict conditions, poverty, and squalor in Mauritius, without water or sanitation, where the entire population of Diego Garcia was deported and dumped by ship, and the expulsion completed in 1975. Pilger tells us that members of the Chagossian population, devastated by their conditions and fate, turn to prostitution, begin to commit suicide, and die of "sadness", while the British government feigned ignorance of these factors. Contrasting images show US army men and their families enjoying a life of luxury and comfort, sunbathing on the beaches, as well as "honeymooners"', as Pilger calls them, basking in the captivating beauty of the island.

\footnotetext{
${ }^{1}$ John Pilger's Stealing a Nation won both the Royal Television Society's top award as Britain's Best Single Documentary in 2004-5, and a 'Chris Award' at the Columbus International Film and Video Festival. For further details on Pilger's productions visit: http://johnpilger.com/videos/stealing-a-nation/, accessed December 15, 2016.
} 
We learn in voiceover that, as a terror tactic, over 1000 pet dogs on the island were ordered to be killed (gassed using the exhaust fumes from American military vehicles) by the Governor of Mauritius as a warning to the Chagossians of further devastation that could follow, including bombings. This heartless killing of children's pets was meant to instill a lasting fear and trauma that would accelerate the islander's willingness to exit from Diego Garcia. As a deportee, Lizette, informs us in the film: "They put the dogs in a furnace where the people worked, and when their dogs were taken away in front of them, our children screamed and cried....My children died from sadness. When we were forced out, she died, the youngest fell ill and the doctor said to me, 'I can't treat sadness'. What they did to us was no different from the treatment of the slaves."

Chagossians who air their views in the film include Rita Bancoult, now in her 70s, who lost her husband and three children after deportation: "I am a British citizen and they threw us out of our homeland in the name of the Queen." Another deportee, Charlesia, shares her views on the US-British conspiracy: "What hurts most is that we were never told what they were doing with our islands. If it had been built for poor people to work, fine. But it's a base for bombers - and the bombs that fell on Iraq came from our paradise."

Part Two of the film shows another generation of Chagossians taking up the struggle for justice, such as Olivier Bancoult who we see as the Leader of Chagos Refugees. We learn that as a result of the Chagossians consistent fight for justice, in 1983 the British government gave the islanders a compensation of 3000 pounds each as settlement after taking their signatures and thumbprints on legal documents that would deprive them of any future claims. This transaction virtually deprived the islanders of ownership of their native land as most signed documents they did not even understand. Robin Mardemootoo, lawyer for Chagos Islanders interviewed in the film, points out that the same year the British government spent 2 billion pounds defending the rights of the Falkland islanders, also British, but the difference being that they were "white."

Following the discovery of secret files lying in the London Records Department by the Chagossians and their representatives fighting for justice, Pilger reconstructs events depicting the expedition of British Foreign Office policies dating back to 1965. We are shown the conspiracy to form the British Indian Ocean Territory (BIOT) that would merit the Chagossians merely as "contract workers" and thereby not an "indigenous" or "permanent population" belonging to Diego Garcia -hence a "floating population" that was to be expelled. However, on the other hand, voiceover in archival clips from a 1957 film, namely "A Colonial Film Unit Production," exposes the duplicity of the US-British secret deal, decided and sealed at the highest levels of government, by identifying the Chagossians as "permanent inhabitants" of the islands.

Moving the focus to Washington D.C., Pilger shows us that along parallel lines a similar conspiracy was taking place in high secrecy in the US where the American government disguised the payment for the lease of the Diego Garcia islands as a \$14 million discount on an American Polaris nuclear missile about to be supplied to the British Royal Navy. ${ }^{2}$ As Pilger confronts James Schlesinger, who served as US Secretary of Defense from 1973-75, about the secret US-British deal and the expulsion of the Chagossians, he simply dismisses the issue as "irrelevant" in the present. However, in the very next scene we learn that the matter was "relevant" enough as in November 2000 the British High Court in London ruled that the expulsion of the Islanders was "illegal," thereby awarding a long-fought victory to the islanders.

Part Three of the film narrows down to the short-lived significance of the British court verdict as within hours the British Foreign and Commonwealth Office announces that they will not allow the islanders to return to Diego Garcia, which remains a British sovereign territory, as are indeed the islanders British citizens. Following the verdict, the British government resorts to once again invoking a quaint loophole in the British governance system to maintain the secret deal with the US. Through a filmic reconstruction of events, we see the workings of what Pilger describes as the "Ordering Council," an "archaic royal decree invested in the Queen to rubber-stamp what

\footnotetext{
${ }^{2}$ For details on the British government's political maneuverings to cover up its actions regarding Diego Garcia and its displaced population, see John Pilger, "Expelled to make way for an US military base, John Pilger cheers the islander fighting dirty tricks," New Statesman, October 18, 2004. Accessed September 15, 2017, http://www.newstatesman. com/node/192510.
} 
politicians cannot get away with democratically." Used earlier by the Harold Wilson government in 1965 to secretly begin expelling all subjects from the Chagos Islands, we see the same Ordering Council being invoked at the Buckingham Palace in 2004 where in a brief verbal ritual the Queen gives her consent, thereby banning the Chagossians from ever returning to their islands. We learn from the filmmaker that the proceedings of the Ordering Council are "never seen by the public, while the Parliament is merely informed about it afterwards."

As Stealing a Nation winds its way to conclusion, we learn from Pilger that the British government declared the Chagos Islands as "unlivable" due to fear of "sinking" under their weight, and hence the high cost that would be involved in resettling the islanders. However, in contrast, clips of US troops and their families making their home on the very same land, and enjoying the beaches on the island contradict British claims of "sinking." As the film ends with footage of Chagossians protesting on the streets of Mauritius to go "home," Pilger's concluding remarks point to US power to dominate the world as the underlying reason for the Chagossian's tragedy, and the need to support and uphold the British High Court decision. It is pertinent to note here that despite having lost their court battle to return to their native island in the European Court in 2012, the Chagossian's struggle for justice nevertheless continues. ${ }^{3}$

Pilger's film sets out to confront and expose what he presents as the web of lies and ruthless official policies that were put in place by the British government to "cleanse" Diego Garcia of its inhabitants and past. Piecing together the story from the perspective of the displaced Chagossians and their testimonies, and supported by archival research and government paper trails that lend the film its authenticity, Stealing a Nation plays what film scholar Bill Nichols refers to as the deliberative and legislative role of documentary cinema in preserving their collective ordeal as a historical reminder of human rights violations of the past that need to be rectified in the present. ${ }^{4}$ The role of the filmmaker as the storyteller, here as an investigative journalist, restores and rescues the past through a filmic re-colonization of the Diego Garcia Island through the reconstruction and reminiscences of its former, aging inhabitants who find their morale and means ruptured to return to their homes and reorganize as a community.

As a filmic documentation, Stealing a Nation acts as a catalyst for the expelled islanders to record visual testimonies of injustice, and their geographical, historical, emotional, and cultural displacement as a community, hence confronting the "epic lie" that Pilger points to. Stripped of their past collective identity and homes, and forced onto a land (Mauritius) that is alien to them, we see that the Chagossians are also simultaneously deprived of the rituals, customs and ceremonies that sociologist Paul Connerton refers to as the sociological and historical means by which societies remember, memorialize, and evolve their identity and sense of community. ${ }^{5}$

The subjectivity/objectivity debate that documentary compilations such as Stealing a Nation highlight can also be seen as how insider/outsider accounts of the same events in retrospect can contradict official historical accounts, leading to a debate and resistance based on collective memory that serves to not only present and record an alternative view, for example, as in Michael Moore's highly provocative and controversial multiple award-winning documentary Fahrenheit 9/11 (2004), but also becomes the key factor in a resistance movement for social and political justice, thus keeping the issue alive. As a human rights documentation that aims to mobilize public opinion and push for justice, Stealing a Nation keeps a compelling political and human rights issue dating back to the 1960s alive and in the public consciousness well into the next century. Backed by archival research, investigative journalism, and interviews with the displaced inhabitants of Diego Garcia as primary sources, the film serves as an authentic visual testimony and documentation of a very important slice of guarded history, and is instrumental in drawing attention to an otherwise little known historical past that has impacted contemporary world events. As an act of filmic activism and resistance on behalf of the displaced islanders, Stealing a Nation creates cross-cultural awareness

\footnotetext{
${ }^{3}$ For details on the court verdict see Alex Spillius, "Chagos Islanders Defeated in European Court." The Telegraph. December 20, 2012, accessed September 15, 2017 at http://www.telegraph.co.uk/news/worldnews/ africaandindianocean/9758451/Chagos-Islanders-defeated-in-European-Court.html..

${ }^{4}$ Bill Nichols, Introduction to Documentary (Bloomington and Indianapolis: Indiana University Press, 2001), 70.

${ }^{5}$ Paul Connerton, How Societies Remember (Cambridg: Cambridge University Press, 1989), 49-50.
} 
by bringing the submerged accounts and oral histories of a forgotten people to public notice that film scholar Michael Renov points to as a valuable service rendered by the documentarist as a revisionist historian. ${ }^{6}$ In turn, the filmic documentation and the representation of its subjects challenges the international justice and human rights organizations for the long overdue justice and compensation for the expelled victims. ${ }^{7}$

In Stealing a Nation Pilger rescues a past laden with trauma, injustice, and betrayal, rendering it as a document of visual history that incorporates the victims' versions as a crucial rejection of official and politically motivated and fabricated history. In doing so, the film serves as a socio-political comment and documentary proof of historical memory, and human-rights violations, which in turn supports the global anti-war resistance movements in the wake of the US military invasions of Afghanistan and Iraq. Correspondingly, John Pilger's painstaking investigation of British and USA government documents and their secret paper trail, archival research, documentation of the testimonies of Diego Garcia's victimized population and their politically and geographically erased histories, interviews with the displaced Chagossian islanders, lawyers, human rights activists, and British and US government officials, reconstructs and memorializes a history and atrocities that would otherwise be forgotten, or lost to time. As of now, the case filed by the Chagos refugees in UK seeking their right to re-settle in Diego Garcia continues in the UK Supreme Court while it upholds the ban on their return. ${ }^{8}$. Pilger's documentary serves as an activist and pedagogical tool in the service of human rights, becoming a part of the social and political movement for justice that requires "remembering and telling the truth about terrible events" referred to by psychiatrist and trauma scholar Judith Herman as a pre-requisite for the restoration of the social order and healing of the forcibly displaced individual victims of Diego Garcia. ${ }^{9}$ In doing so, the film presses for justice for the Chagossian's forcible expulsions from their ancestral habitat, an act that the International Criminal Court describes as a crime against humanity. ${ }^{10}$

Title of the Film: Stealing a Nation; Director: John Pilger; Reconstruction Director: Sean Crotty; Producers: John Pilger; Cinematography: Preston Clothier; Film Editors: Joe Frost; Sound Designer: Zubin Sarosh; Country: UK; Year of Release: 2004; Production Company: Independent Television. Duration: 54 minutes.

\footnotetext{
${ }^{6}$ Michael Renov, “Towards a Poetics of Documentary," in Theorizing Documentary, ed. Michael Renov. (New York and London: Routledge, 1993), 27.

${ }^{7}$ The Chagossian islanders' struggle for justice continued as they took their case to the European Court of Human Rights. John Pilger. "Paradise Cleansed." Accessed at: http://www.informationclearinghouse.info/video1027.htm on December 15, 2016.

${ }^{8}$ McQue, Katie. “UK Supreme Court Highlights Right of Chagos Refugees to Return Home.” New Internationalist Magazine. July 5, 2016. Accessed at: https://newint.org/features/web-exclusive/2016/07/05/uk-supreme-courthighlights-right-of-chagos-refugees-to-return/ on December 15, 2016.

9 Judith Lewis Herman, Trauma and Recovery: the Aftermath of Violence: from Domestic Abuse to Political Terror (New York, Basic Books, 1992), 1.

10 "Article 7 of the statute of the international criminal court describes the "deportation or forcible transfer of population ... by expulsion or other coercive acts" as a crime against humanity." Pilger, John. 'Paradise Cleansed.' The Guardian, October 2, 2004. Accessed at: http://www.theguardian.com/politics/2004/oct/02/foreignpolicy.comment on December $15,2016$.
} 